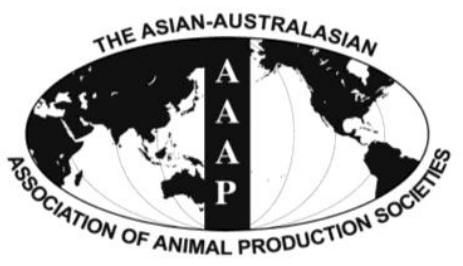

Asian Australas. J. Anim. Sci.

Vol. 26, No. 10 : 1437-1445 October 2013

http://dx.doi.org/10.5713/ajas.2013.13143

www.ajas.info

pISSN 1011-2367 elSSN 1976-5517

\title{
Effects of Feeding Increasing Proportions of Corn Grain on Concentration of Lipopolysaccharide in the Rumen Fluid and the Subsequent Alterations in Immune Responses in Goats
}

\author{
Wenjie Huo, Weiyun Zhu, and Shengyong Mao* \\ Laboratory of Gastrointestinal Microbiology, College of Animal Sciences and Technology, \\ Nanjing Agricultural University, Nanjing 210095, China
}

\begin{abstract}
This study was conducted to investigate the effects of feeding increasing proportions of corn grain on concentration of lipopolysaccharide (LPS) in the rumen fluid and the subsequent alterations in immune responses as reflected by plasma concentrations of serum amyloid A (SAA) and haptoglobin (Hp) in goats. Nine goats were assigned to three diets $(0 \%, 25 \%$, and $50 \%$ corn grain) in a 3 $\times 3$ Latin square experimental design. The results showed that as the proportion of dietary corn increased, the ruminal $\mathrm{pH}$ decreased $(\mathrm{p}<$ $0.001)$, and the concentrations of propionate $(\mathrm{p}<0.001)$, butyrate $(\mathrm{p}<0.001)$, lactic acid $(\mathrm{p}=0.013)$ and total volatile fatty acid $(\mathrm{p}=$ 0.031 ) elevated and the ruminal LPS level increased $(\mathrm{p}<0.001)$. As the proportion of dietary corn increased, the concentration of SAA increased $(\mathrm{p}=0.013)$. LPS was detectable in the blood of individual goats fed $25 \%$ and $50 \%$ corn. A real-time PCR analysis showed that the copy number of phylum Bacteroidetes $(\mathrm{p}<0.001)$ was reduced $\left(4.61 \times 10^{9} \mathrm{copies} / \mathrm{mL}\right.$ to $1.48 \times 10^{9}$ copies $\left./ \mathrm{mL}\right)$ by the increasing dietary corn, and a correlation analysis revealed a significant negative correlation between the number of Bacteroidetes and rumen LPS levels. Collectively, these results indicated that feeding goats high proportions (50\%) of corn grain decreased the ruminal pH, increased LPS in the rumen fluid and tended to stimulate an inflammatory response. (Key Words: Goat, Haptoglobin, High Corn Grain Diet, Lipopolysaccharide, Serum Amyloid A)
\end{abstract}

\section{INTRODUCTION}

It is a common practice to feed ruminant animals amount of concentrate to accelerate milk production and body weight gain. However, feeding diets high in readily fermentable carbohydrates increases the odds of developing subacute ruminal acidosis (SARA) and decreases the longterm productive performance of beef and milk (Stone, 2004). In addition, numerous studies have recently demonstrated that feeding cattle diets rich in highly degradable carbohydrates results in disorders such as acidosis, fatty liver, laminitis, liver abscesses, displaced abomasum, and bloat (Nocek, 1997; Ametaj et al., 2005). Although the exact mechanisms underlying the relationship between feeding large amounts of cereal grains and the high incidence of metabolic diseases is not yet completely understood, research has described several events associated with feeding high grain diets. For example,

\footnotetext{
* Corresponding Author: Shengyong Mao. Tel: +86-25-84395523, E-mail: maoshengyong@163.com

Submitted Mar. 8, 2013; Accepted May 8, 2013; Revised Jun. 3, 2013
}

digestion of increasing amounts of cereal grains was shown to initiate major changes in the composition of microbiota in favor of Gram-negative bacteria (Dunlop, 1972). Additionally, other researchers found that bacterial alterations were associated with the release of large amounts of lipopolysaccharide (LPS), a cell-wall component of all Gram-negative bacteria, in the rumen fluid (Nagaraja et al., 1978; Andersen et al., 1994; Gozho et al., 2006; Li et al., 2012). This increase in luminal LPS could increase rumen permeability, lead to the translocation of LPS or other immunogenic compounds into circulation, and trigger systemic inflammatory response (Ametaj et al., 2007; Khafipour et al., 2009).

Worldwide, the goat population is approximately 909 million (FAO: 2010, Yearbook statistics. Available at: http://faostat.fao.org/site/573/default.aspx\#ancor). In the last $20 \mathrm{yrs}$, the goat population increased $53.88 \%$ worldwide. In China, goat production is the largest production among ruminants. This may be because goats have stronger roughage resistance and stress resistance than cows and sheep, considering that China is short of good 
quality of forages and consequently large amount of roughages and grains are used for ruminants. In addition, despite previous researches have demonstrated that high grain feeding increases the concentrations of the acute phase proteins serum amyloid A (SAA), and haptoglobin (Hp), which are markers of inflammation, in peripheral blood of cattle and sheep (Gozho et al., 2005; 2007; González et al., 2008, Nazifi et al., 2009), to our knowledge, little information is available on the concentration of LPS in the rumen fluid and the subsequent alterations in immune responses during high grain feeding in goats.

We hypothesised that feeding high proportions of corn grain could increase the ruminal LPS concentration, ultimately resulting in changes in SAA or $\mathrm{Hp}$ in peripheral blood in goats. Therefore, the main objective of this study was to determine if feeding high proportions of corn grain could result in increases in the concentration of ruminal LPS and stimulate an inflammatory response in goats, in addition, the effects of high grain feeding on changes in the composition of rumen bacterial community were also determined.

\section{MATERIALS AND METHODS}

\section{Ethics}

All of the management, ethical and experimental procedures were conducted according to the Guidelines for the Care and Use of Animals at Nanjing Agricultural University, 1999.

\section{Animals and diets}

A total of nine male goats $(25 \pm 3 \mathrm{~kg})$ fitted with ruminal cannulas were used in this study in a $3 \times 3$ Latin square design. The each experimental period was $21 \mathrm{~d}$, with the first $14 \mathrm{~d}$ used for diet adaptation and the last $7 \mathrm{~d}$ used for measurements. The animals were housed in individual pens with free access to water and were fed twice daily at 08:00 $\mathrm{h}$ or 20:00 h. Dry matter intake was $600 \mathrm{~g} / \mathrm{d} / \mathrm{head}$. To challenge the goats with graded amounts of rumen fermentable carbohydrates, the basic ration was 0,25 , or $50 \%$ (DM) corn grain to provide three different dietary treatments. All of the diets were formulated to meet the nutrient requirements of a $25 \mathrm{~kg}$ meat goat as per NRC (2007) guidelines (Table 1).

\section{Sample collection}

Samples of the rumen contents (approx, $50 \mathrm{~mL}$ ) were obtained on $\mathrm{d} 1,3,5$, and 7 of the measurement day shortly before the morning feeding $(07: 45 \mathrm{~h})$ and at $2 \mathrm{~h}, 4 \mathrm{~h}$ and $8 \mathrm{~h}$ after feeding. All of the rumen content samples were collected through the rumen cannula into a $140 \mathrm{~mL}$ plastic container. According to Mao et al. (2008), $3 \mathrm{~mL}$ of the rumen contents collected on $\mathrm{d} 7$ of measurement day before
Table 1. Composition and ingredients of experimental diets

\begin{tabular}{|c|c|c|c|}
\hline \multirow[t]{2}{*}{ Item } & \multicolumn{3}{|c|}{$\begin{array}{l}\text { Corn grain proportion } \\
\text { (\% of diet dry matter) }\end{array}$} \\
\hline & 0 & 25 & 50 \\
\hline \multicolumn{4}{|l|}{ Ingredient, $\%$ of DM } \\
\hline Corn grain & 0 & 25 & 50 \\
\hline Soy bean meal & 8 & 8 & 8 \\
\hline Alfalfa & 10 & 6 & 3 \\
\hline Chinese wildrye & 80 & 59 & 37 \\
\hline Dicalcium phosphate & 0.5 & 0.5 & 0.5 \\
\hline Salt & 0.5 & 0.5 & 0.5 \\
\hline Mineral and vitamin premix ${ }^{a}$ & 1 & 1 & 1 \\
\hline \multicolumn{4}{|l|}{ Nutrient composition (\% DM) } \\
\hline Dry matter & 94.81 & 92.4 & 90.94 \\
\hline Organic matter & 92.47 & 93.37 & 94.86 \\
\hline Crude protein & 10.08 & 10.50 & 10.66 \\
\hline Ether extract & 1.93 & 2.56 & 2.76 \\
\hline Neutral detergent fibre (NDF) & 36.76 & 32.36 & 26.76 \\
\hline Calcium & 0.60 & 0.48 & 0.38 \\
\hline Phosphorus & 0.09 & 0.11 & 0.14 \\
\hline $\begin{array}{l}\text { Metabolizable energy } \\
(\mathrm{MJ} / \mathrm{kg} \mathrm{DM})\end{array}$ & 8.09 & 8.93 & 9.87 \\
\hline
\end{tabular}

${ }^{a}$ Contained $7 \mathrm{~g} / \mathrm{kg}$ of Fe, $8 \mathrm{~g} / \mathrm{kg}$ of $\mathrm{Zn}, 5 \mathrm{~g} / \mathrm{kg}$ of $\mathrm{Mn}, 1.2 \mathrm{~g} / \mathrm{kg}$ of $\mathrm{Cu}, 130$ $\mathrm{mg} / \mathrm{kg}$ of I, $27 \mathrm{mg} / \mathrm{kg}$ of Se, $45 \mathrm{mg} / \mathrm{kg}$ of Co, 1,100,000 IU $/ \mathrm{kg}$ of vitamin $\mathrm{A}, 300,000 \mathrm{IU} / \mathrm{kg}$ of vitamin $\mathrm{D}$, and 3,200 IU of vitamin E.

the morning feeding $(07: 45 \mathrm{~h})$ was used for DNA extraction (Mao et al., 2008). The other rumen samples were strained through four layers of cheesecloth, and the $\mathrm{pH}$ of the rumen fluid was measured immediately after collection using a mobile $\mathrm{pH}$ meter. A $2 \mathrm{~mL}$ aliquot of freshly prepared $25 \%$ $(250 \mathrm{~mL} / \mathrm{L})$ meta-phosphoric acid was added to $8 \mathrm{~mL}$ of strained ruminal fluid; the mixture was centrifuged $(17,000$ $\mathrm{g}$ for $10 \mathrm{~min}$ ), and the supernatant fluid was stored at $-20^{\circ} \mathrm{C}$ for determination of the volatile fatty acids (VFA). A $5 \mathrm{~mL}$ sample of the rumen fluid was used for the LPS content measurement, and the remaining rumen fluid samples were stored at $-20^{\circ} \mathrm{C}$ for the lactic acid analysis. Starting at 08:00 on $\mathrm{d} 7$, samples of ruminal fluid were collected every $2 \mathrm{~h}$ up to 20:00 to investigate the diurnal responses of the $\mathrm{pH}$.

Blood samples were obtained from the jugular vein on $\mathrm{d}$ 7 of the measurement period at $07: 45 \mathrm{~h}$, shortly before the 08:00 $\mathrm{h}$ morning feeding, and at $4 \mathrm{~h}$ and $8 \mathrm{~h}$ after feeding. Sodium-heparinised, pyrogen-free, $10 \mathrm{~mL}$ vacuum glass tubes were used to collect the blood samples. Immediately after collection, the blood samples were stored on ice, and the plasma was separated within 20 min of withdrawal by centrifuging at $3,000 \mathrm{~g}$ at $4^{\circ} \mathrm{C}$ for $20 \mathrm{~min}$. A portion of the plasma was transferred to pyrogen-free glass tubes and stored at $-20^{\circ} \mathrm{C}$ until the LPS was analysis. The remaining plasma was divided into aliquots of $2 \mathrm{~mL}$ and stored at $-20^{\circ} \mathrm{C}$ until analysis for SAA and $\mathrm{Hp}$. 


\section{Extraction of genomic DNA}

The DNA was extracted according to a bead-beating method using a mini-bead beater (Biospec Products), followed by phenol-chloroform extraction (Mao et al., 2008). The solution was then precipitated with isopropanol, and the pellets were suspended in $50 \mu \mathrm{L}$ Tris ethylene diamine tetraacetic acid (TE). The DNA samples were quantified using a Nanodrop spectrophotometer (Nyxor Biotech).

\section{Real-time PCR assay for the quantification of the Firmicutes and Bacteroidetes}

Real-time PCR was performed using an Applied Biosystems 7300 Real-Time system (Applied Biosystems) with phylum Firmicutes and Bacteroidetes primers (Guo et al., 2008). The reaction mixture $(20 \mu \mathrm{L})$ consisted of $10 \mu \mathrm{L}$ IQ SYBR Green Supermix (Bio-Rad), 0.2 M each oligonucleotide primer set and $1 \mu \mathrm{L}$ template DNA. The measurements were performed in triplicate for each run, including a negative control. The amount of DNA in each sample was spectrophotometrically determined in triplicate using a GeneQuant pro RNA/DNA calculator (Amersham Biosciences), and the mean values were calculated. The DNA concentration of the PCR product measured using the GeneQuant pro RNA/DNA calculator can be directly related to the copy number using the following equation: copy number $/ \mu \mathrm{L}=(\mathrm{C} / \mathrm{X}) \times 0.912 \times 1012$, where $\mathrm{C}$ is the DNA measured concentration $(n g / \mu \mathrm{L})$ and $\mathrm{X}$ is the PCR fragment or plasmid length (base bp/copy). PCR was performed using one cycle of $95^{\circ} \mathrm{C}$ for $2 \mathrm{~min}$, then 40 cycles at $95^{\circ} \mathrm{C}$ for $15 \mathrm{~s}$ and $60^{\circ} \mathrm{C}$ for $1 \mathrm{~min}$ (Denman and McSweeney, 2006).

\section{Chemicals analysis}

Samples of the concentrate, Chinese wildrye (Leymus chinensis) and alfalfa hay were collected during the data collection week, ground to pass through a $1 \mathrm{~mm}$ screen and analysed for dry matter (DM) (method 930.15; AOAC, 1995), ash (method 942.05; AOAC, 1995), ether extract (method 920.39; AOAC, 1995), neutral detergent fibre (NDF; Van Soest et al., 1991), The crude protein (CP) $(\mathrm{N} \times 6.25)$ was determined by the method of Krishnamoorthy et al. (1982), and the VFA in the ruminal fluid were measured using a capillary column gas chromatograph (Shimadzu, GC-14A) (Mao et al., 2008). The lactic acid concentration was analysed following the method described by Baker and Summerson (1941).

\section{Rumen LPS analysis}

As described by Emmanuel et al. (2008), the concentration of cell-free LPS in the rumen fluid supernatant was determined by the Limulus amoebocyte lysate (LAL) assay (Xiamen Houshiji, Ltd., Xiamen, China).
Five millilitres of rumen fluid were centrifuged at 10,000 $\mathrm{g}$ for $45 \mathrm{~min}$ at $4^{\circ} \mathrm{C}$, and the supernatant was aspirated gently to prevent its mixing with the pellet and passed through a disposable $0.22 \mu \mathrm{m}$ sterile, pyrogen-free filter (Fisher Scientific). The filtrate was collected in pyrogen-free glass tubes and heated at $100^{\circ} \mathrm{C}$ for $30 \mathrm{~min}$. The samples were cooled at room temperature $\left(20^{\circ} \mathrm{C}\right)$ for $10 \mathrm{~min}$ and stored at $-20^{\circ} \mathrm{C}$ until analysis. For the assay, the rumen fluid was diluted 10,000-fold using the LAL reagent water and pyrogen-free test tubes (Xiamen Houshiji, Ltd., Xiamen, China). The method and the quantities of the reagents described in the kit were modified to produce greater standard ranges of 0.01 to 10 endotoxin units $(\mathrm{EU}) / \mathrm{mL}$. A control standard LPS, containing 10 EU endotoxin per vial, was used to prepare the standard solutions. All of the samples were tested in duplicate, and the optical density values were measured using a microplate spectrophotometer (Spectramax 190, Molecular Devices Corporation), at a wavelength of $405 \mathrm{~nm}$.

\section{Plasma LPS analysis}

As described by Khafipour et al. (2009a), the concentration of LPS in the plasma was determined by the LAL assay (Xiamen Houshiji, Ltd., Xiamen, China) with a minimum detection limit of $0.01 \mathrm{EU} / \mathrm{mL}$. Before the LAL assay, the samples were pretreated as described by Khafipour et al. (2009a). Frozen plasma samples were thawed at $37^{\circ} \mathrm{C}$ and vortexed, then $100 \mu \mathrm{L}$ of each sample was diluted at least 10 -fold with pyrogen-free water. The diluted samples were incubated at $37^{\circ} \mathrm{C}$ for $30 \mathrm{~min}$, heated at $75^{\circ} \mathrm{C}$ for $15 \mathrm{~min}$ and cooled to room temperature $\left(19^{\circ} \mathrm{C}\right)$ for $45 \mathrm{~min}$. The LAL assay was performed using a 96 well microplate according to the manufacturer's instructions. All of the samples were tested in duplicate, and the optical density values were measured using a microplate spectrophotometer (Spectramax 190, Molecular Devices Corporation) at a wavelength of $405 \mathrm{~nm}$. The results were accepted when the intra-assay coefficient of variation was $<10 \%$. The minimum detection level of LPS in the plasma was $0.01 \mathrm{EU} / \mathrm{mL}$ using this method.

\section{Plasma acute-phase proteins}

The plasma concentrations of $\mathrm{Hp}$ and SAA were determined using ELISA kits (TP-801, and TP-802, respectively, Tri-Delta Diagnostics), as described by Gozho et al. (2005). The samples were initially diluted 1:5 for $\mathrm{Hp}$ and 1:500 for SAA and assayed according to the manufacturer's instructions. The samples were analysed in duplicate, and the absorbance values were measured at 630 $\mathrm{nm}$ for $\mathrm{Hp}$ and $450 \mathrm{~nm}$ for SAA using a microplate spectrophotometer (Spectra Max 340 PC, Molecular Devices Corp.). 


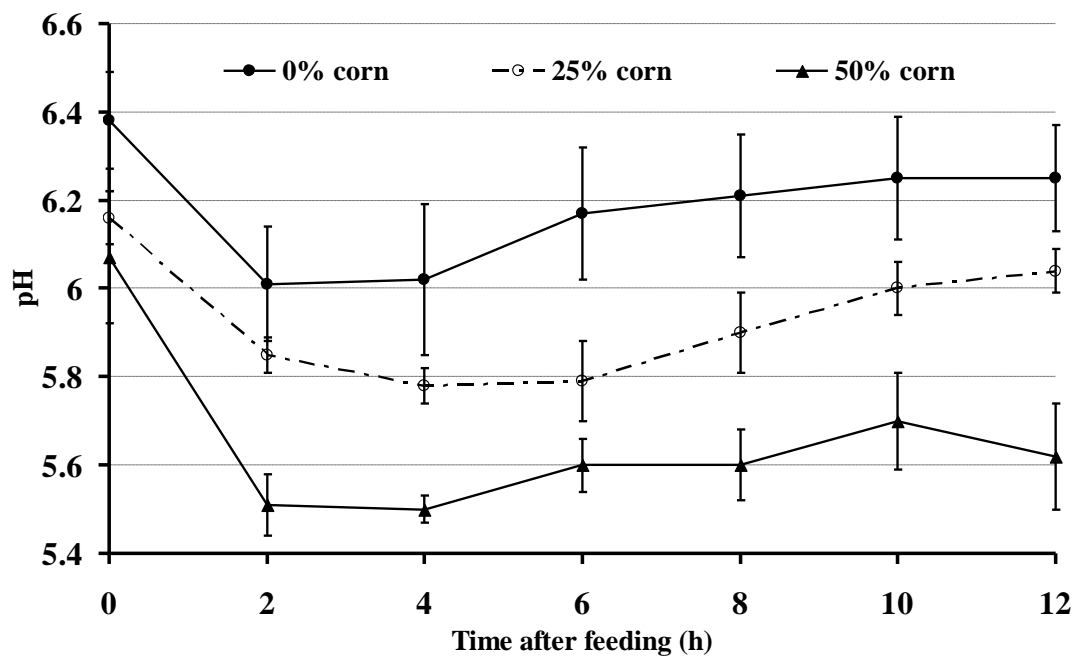

Figure 1. The daily rumen $\mathrm{pH}$ variation during the $12 \mathrm{~h}$ after morning feeding $(\mathrm{n}=9)$.

\section{Data analysis}

To test the influence of the diet on the lactic acid, VFA, LPS, rumen $\mathrm{pH}$, SAA and Hp concentrations, the MIXED procedure was performed using the diet, period and day as fixed effects and the goats as a random effect. The samples collected at different times for the same goat were considered as repeated measures in the analysis of variance (ANOVA). Within the model, the differences of the least squares means were compared using a Bonferroni t test only after for a significant effect was found for the diet. The data were compiled into the means \pm standard errors of the mean (SEM) using PASW Statistics 18 (SPSS), and the level of significance was set at $\mathrm{p}<0.05$.

For the ruminal bacteria community parameters, the general linear model (GLM) procedure was performed with diet and period as fixed effects. The data were compiled into the means \pm SEM using PASW Statistics 18 (SPSS), and the level of significance was set at $p<0.05$.

Correlations between each microbial dataset and the LPS levels were assessed using Pearson's correlation test with GraphPad Prism (5.00). Significance was declared at $\mathrm{p}<0.05$

\section{RESULTS}

\section{Effect of a high grain diet on the diurnal rumen $\mathrm{pH}$}

The diurnal data indicated that the goats fed the $0 \%$ corn grain diet had a higher ruminal $\mathrm{pH}$ compared with the $25 \%$ and $50 \%$ corn groups $(\mathrm{p}<0.001)$ (Figure 1$)$. The ruminal $\mathrm{pH}$ also varied over the time during the day $(\mathrm{p}<0.001)$. In general, the ruminal $\mathrm{pH}$ in all of the goats declined during the first few hours after the morning feeding, regardless of the diet used. However, during the time period from almost $1 \mathrm{~h}$ after feeding until the sampling at $12 \mathrm{~h}$, the average ruminal $\mathrm{pH}$ was $<5.8$ in the $50 \%$ corn group and remained significantly lower than that of the $0 \%$ corn group; the duration for a ruminal $\mathrm{pH}$ below 5.8 was approximately 10 $\mathrm{h}$ after the first feeding in the $50 \%$ corn group.

Effect of a high grain diet on the rumen $\mathrm{pH}$, rumen fluid composition and free LPS

The rumen $\mathrm{pH}$, rumen fluid composition and LPS concentration are presented in Table 2. As the proportion of dietary corn increased, the rumen $\mathrm{pH}$ decreased $(\mathrm{p}<0.001)$, the propionate $(\mathrm{p}<0.001)$, butyrate $(\mathrm{p}<0.001)$, isobutyrate $(\mathrm{p}$ $=0.079)$, valerate $(\mathrm{p}<0.001)$, isovalerate $(\mathrm{p}<0.001)$, total volatile fatty acid (TVFA) $(\mathrm{p}<0.031)$ and lactic acid $(\mathrm{p}=$ $0.013)$ concentrations increased. The LPS concentration in the rumen liquid increased $(\mathrm{p}<0.001)$ as the proportion of dietary corn increased.

Effects of a high grain diet on the concentrations of serum amyloid $A$ and haptoglobin in peripheral blood

Changes in the concentrations of SAA and $\mathrm{Hp}$ in the peripheral blood are shown in Table 3. As the proportion of dietary corn increased, the data indicated potential increases in the concentrations of $\mathrm{Hp}(\mathrm{p}=0.152)$ in the blood, and the concentration of SAA increased significantly $(\mathrm{p}=0.013)$. LPS was detected in the peripheral blood in three of nine goats in the $25 \%$ corn group $(0.406,0.846$ and 0.241 $\mathrm{EU} / \mathrm{mL}$, respectively, data not shown) and $50 \%$ corn group $(0.243,0.126$, and $1.47 \mathrm{EU} / \mathrm{mL}$, respectively, data not shown). In the control, however, LPS was not detected (Table 3).

Effect of a high grain diet on the 16s rRNA gene copy number of Firmicutes and Bacteroidetes and its relationship with the rumen LPS levels

The real-time PCR showed that, as the proportion of dietary corn increased, the copy number of phylum 
Table 2. Rumen $\mathrm{pH}$, rumen fluid composition and LPS concentration

\begin{tabular}{|c|c|c|c|c|c|}
\hline & \multicolumn{3}{|c|}{ Corn grain proportion $(\% \mathrm{DM})$} & \multirow{2}{*}{ SEM } & \multirow{2}{*}{$\mathrm{p}$ value } \\
\hline & 0 & 25 & 50 & & \\
\hline$\overline{R u m i n a l ~ p H}$ & $6.28^{\mathrm{a}}$ & $5.93^{\mathrm{b}}$ & $5.65^{\mathrm{c}}$ & 0.039 & 0.018 \\
\hline Acetate $(\mathrm{mmol} / \mathrm{L})$ & 62.73 & 60.49 & 59.49 & 0.960 & 0.053 \\
\hline Propionate (mmol/L) & $12.31^{\mathrm{b}}$ & $12.77^{\mathrm{b}}$ & $14.11^{\mathrm{a}}$ & 0.244 & $<0.001$ \\
\hline Isobutyrate $(\mathrm{mmol} / \mathrm{L})$ & $1.48^{\mathrm{b}}$ & $1.63^{\mathrm{a}}$ & $1.65^{\mathrm{a}}$ & 0.058 & 0.079 \\
\hline Butyrate (mmol/L) & $5.35^{\mathrm{b}}$ & $8.79^{\mathrm{a}}$ & $10.71^{\mathrm{a}}$ & 0.180 & $<0.001$ \\
\hline Isovalerate $(\mathrm{mmol} / \mathrm{L})$ & $0.49^{\mathrm{c}}$ & $0.62^{\mathrm{b}}$ & $0.71^{\mathrm{a}}$ & 0.044 & $<0.001$ \\
\hline Valerate (mmol/L) & $0.96^{\mathrm{b}}$ & $1.29^{\mathrm{a}}$ & $1.46^{\mathrm{a}}$ & 0.019 & $<0.001$ \\
\hline TVFA (mmol/L) & $83.31^{\mathrm{c}}$ & $85.61^{\mathrm{b}}$ & $88.12^{\mathrm{a}}$ & 1.284 & 0.031 \\
\hline The ratio of acetate to propionate & $5.18^{\mathrm{a}}$ & $4.81^{\mathrm{b}}$ & $4.43^{\mathrm{b}}$ & 0.078 & $<0.001$ \\
\hline Lactic acid (mmol/L) & $0.29^{\mathrm{b}}$ & $0.35^{\mathrm{ab}}$ & $0.44^{\mathrm{a}}$ & 0.035 & 0.013 \\
\hline $\begin{array}{l}\text { LPS concentration } \\
\text { in the rumen liquid }(\mathrm{EU} / \mathrm{mL})\end{array}$ & $5,316^{\mathrm{c}}$ & $21,075^{\mathrm{b}}$ & $35,116^{\mathrm{a}}$ & 6,135 & $<0.001$ \\
\hline
\end{tabular}

$\overline{\mathrm{a}, \mathrm{b}, \mathrm{c}}$ The means within a row with different superscripts differ significantly $(\mathrm{p}<0.05)$.

Table 3. The SAA, Hp and LPS concentrations in blood

\begin{tabular}{lcccrr}
\hline & \multicolumn{3}{c}{ Corn grain proportion $(\% \mathrm{DM})$} & \multirow{2}{*}{ SEM } & p value \\
\cline { 2 - 5 } SAA $(\mu \mathrm{g} / \mathrm{mL})$ & 0 & 25 & 50 & 2.03 & 0.013 \\
Hp $(\mu \mathrm{g} / \mathrm{mL})$ & $13.614^{\mathrm{b}}$ & $16.367^{\mathrm{a}}$ & $15.317^{\mathrm{ab}}$ & 38.11 & 0.152 \\
LPS $(\mathrm{EU} / \mathrm{mL})$ & 353.271 & 402.423 & 384.845 & 0.131 & 0.402 \\
\hline
\end{tabular}

ND $=$ Not detected. ${ }^{a, b}$ The means within a row with different superscripts differ significantly $(p<0.05)$.

Bacteroidetes decreased $(\mathrm{p}<0.001)$, and the ratio of Firmicutes to Bacteroidetes increased $(\mathrm{p}=0.001)$ (Table 4). In contrast, no significant difference was observed in the number of Firmicutes $(p=0.146)$ in the $25 \%$ and $50 \%$ groups compared with the control.

To assess the possible relationship between the bacterial abundance and the LPS level, a correlation analysis was conducted on the two most commonly represented phyla and the LPS concentration. The results showed a significant negative correlation between the abundance of Bacteroidetes and LPS levels $(\mathrm{R}=-0.437, \mathrm{p}=0.023)$ (Figure 2a), whereas no significant correlation was observed between the abundance of Firmicutes and LPS levels $(\mathrm{R}=-0.085, \mathrm{p}=0.665)$ (Figure $2 \mathrm{~b})$.

\section{DISCUSSION}

The $\mathrm{pH}$ of the rumen is a critical factor in the normal and stable function of the rumen because of its profound effect on microbial populations and fermentation and on the physiological functions of the rumen, mainly the motility and absorptive functions. The ruminal $\mathrm{pH}$ can be influenced by the intake of fermentable carbohydrate, and the rates of utilisation and absorption of acids (Nagaraja and Titgemeyer, 2007). The diet in our study containing a high proportion grain was rich in rapidly fermentable carbohydrates, resulting in the decrease in the rumen $\mathrm{pH}$ to acidotic values, with the rumen fluid $\mathrm{pH}$ being below 5.8 for more than $10 \mathrm{~h} / \mathrm{d}$ in the $50 \%$ corn group. Recent studies suggested that duration of episodes during which ruminal $\mathrm{pH}$ remains below 5.8 for longer than $5.4 \mathrm{~h} / \mathrm{d}$ was safer indicators of SARA (Gozho et al., 2007; Zebeli et al., 2008). Thus, based on this definition, the SARA was induced by the 50\% corn grain feeding in this study. On the other hand, we also found, as the proportion of dietary corn increased, the propionate, butyrate, isobutyric acid, valerate, isovalerate and TVFA concentrations increased, while the ruminal lactic acid concentration was low, not exceeding $0.5 \mathrm{mM}$. The generally low lactic acid concentration suggests that an elevated total VFA concentration is the

Table 4. The 16s rRNA gene copies of phylum Firmicutes and Bacteroidetes in rumen

\begin{tabular}{|c|c|c|c|c|c|}
\hline \multirow[t]{2}{*}{ Item } & \multicolumn{3}{|c|}{ Corn grain proportion (\% of DM) } & \multirow{2}{*}{ SEM } & \multirow{2}{*}{$\mathrm{p}$ value } \\
\hline & 0 & 25 & 50 & & \\
\hline Firmicutes $\left(\times 10^{8}\right.$ copies $\left./ \mathrm{mL}\right)$ & 9.56 & 6.43 & 6.17 & 1.289 & 0.146 \\
\hline Bacteroidetes $\left(\times 10^{9}\right.$ copies $\left./ \mathrm{mL}\right)$ & $4.61^{\mathrm{a}}$ & $1.95^{\mathrm{b}}$ & $1.48^{\mathrm{b}}$ & 0.391 & $<0.001$ \\
\hline Firmicutes/bacteroidetes & $0.21^{\mathrm{b}}$ & $0.32^{\mathrm{a}}$ & $0.40^{\mathrm{a}}$ & 0.033 & 0.001 \\
\hline
\end{tabular}

\footnotetext{
$\overline{\mathrm{a}, \mathrm{b}}$ The means within a row with different superscripts differ significantly $(\mathrm{p}<0.05)$.
} 

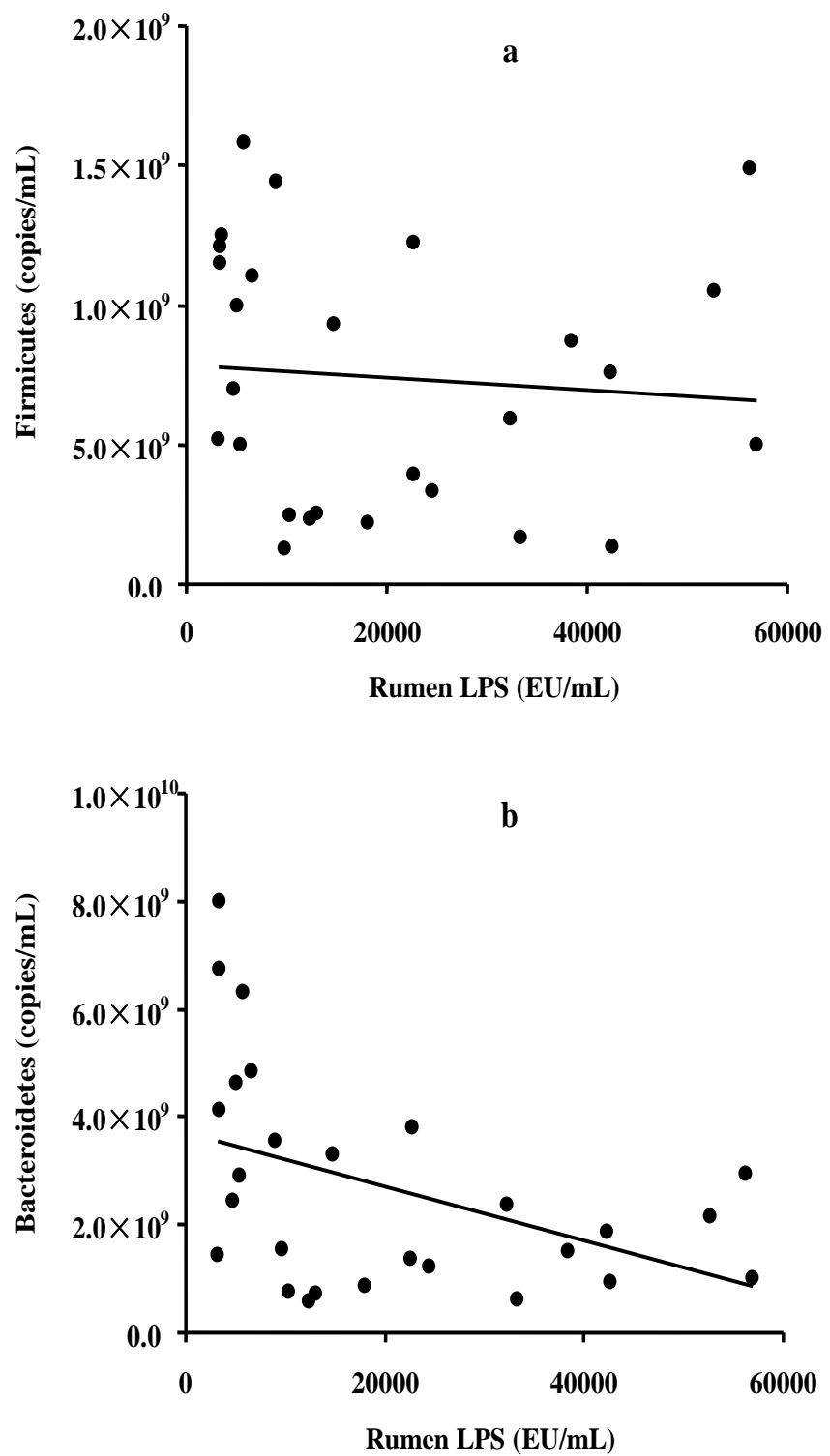

Figure 2. Correlations between the copy numbers of rumen Firmicutes (a) or Bacteroidetes (b) and the rumen LPS concentration.

main cause of a low ruminal $\mathrm{pH}$.

Results are in agreement with our working hypothesis that feeding increasing proportions of corn grain to goats was associated with increased concentrations of LPS in the rumen fluid. Feeding diets containing 25 and 50\% corn grain resulted in higher amounts of free LPS in the rumen fluid compared with those of goats receiving $0 \%$ corn grain. Our findings are consistent with previous studies demonstrating enhanced content of LPS in the rumen fluid from feedlot or dairy cattle fed diets containing high proportions of grain (Andersen, 2003; Emmanuel et al., 2008; Li et al., 2012). Gozho et al. (2006) reported a 3-fold increase in the concentration of LPS in the rumen fluid when steers were moved from an all-forage diet to a $61 \%$ concentrate diet. Interestingly, they failed to detect any changes in the amount of LPS in the rumen from an all- forage to $41 \%$ concentrate diet. In our study, an increase was observed when the amount of corn grain was enhanced from 0 to 25 or $50 \%$, further, an about 7 -fold increase in the concentration of LPS in the rumen fluid when goats were fed the $50 \%$ grain compared with the $0 \%$ control. The difference in results might be related to the difference in the relative amount of grain fed to steers vs. goats, as compared with the steers, goats are fed greater amounts of grain ( $0.014 \mathrm{~kg} /$ body weight vs $0.0075 \mathrm{~kg} /$ body weight).

Two most abundant bacterial phyla that inhabit the rumen are Gram-positive Firmicutes and the Gram-negative Bacteroidetes (Khafipour et al., 2009b; Fernando et al., 2010), and it was known that LPS is a cellular component of Gram-negative bacteria (Andersen, 2003; Emmanuel et al., 2008). Plaizier et al. (2008) reported there is an increase in the concentration of LPS in the rumen in both acute and 
subacute acidosis. Khafipour et al. (2009b) observed a decrease in the number of Bacteroidetes in the rumen as a consequence of a high grain diet. In the present study, the increase in corn grain significantly increased the concentration of LPS in the rumen and decreased the number of Bacteroidetes; furthermore, the correlation analysis showed a negative correlation between the copy number of Bacteroidetes and the ruminal LPS levels. This association might be linked to the high cell autolysis rate of the Gram-negative Bacteroidetes species when accumulating toxic glucose fermentation end products during high grain feeding (Wells and Russell, 1996).

Previous studies reported that luminal LPS can be translocated into the systemic circulation when the concentration of LPS in the lumen of the gastrointestinal tract increased after being fed a high grain diet (Emmanuel et al., 2008; Khafipour et al., 2009a) or the oral administration of large doses of LPS (Aschenbach et al., 2003). It has been suggested that the mechanism of LPS translocation involves an impairment of the barrier function of the rumen epithelium due to the high luminal osmolality, acidic $\mathrm{pH}$ and high concentrations of LPS, which can cause swelling and rupture of ruminal papillae with high grainbased diets (Kleen et al., 2003; Emmanuel et al., 2007). In the present study, the concentration of LPS in peripheral blood was undetectable in all of the goats fed the $0 \%$ grain groups, but it was detectable in some of the goats fed the $25 \%$ and $50 \%$ grain groups, in spite of the fact that the statistical analysis indicated that the concentrations of LPS in the peripheral blood in the $25 \%$ and $50 \%$ grain groups were not different from the control (Table 3 ). These results indicated that an impairment of the barrier function of the rumen epithelium might occur in goats fed a high corn grain diet. However, the fact that LPS became detectable in the blood in some of the goats, but not in others, in the $25 \%$ and $50 \%$ grain groups may be partly explained by the difference between the individual ruminants (Zebeli et al., 2012). In the dairy industry, it is known that the risk for acidosis is not the same for all cows (Beauchemin and Penner, 2009): individual dairy cows exhibit tremendous variation in the degree of acidosis they experience, even when fed and managed similarly (Beauchemin and Penner, 2009). The variation in the degree of acidosis in the rumen may result from a difference in the absorptive functions in individual ruminants and may result in differences in the permeability of the ruminal mucosal tissue. Penner et al. (2009) provided evidence that differences in the absorptive capacity of the ruminal epithelia between individual sheep accounted for a large variation in the ruminal $\mathrm{pH}$ among animals. Chen et al. (2012) showed that there are differences in rumen bacterial diversity and density of both rumen content and epithelium communities between rumen acidosis-susceptible (AS) and acidosis-resistant steers, and a higher bacterial density was detected in AS animals. Therefore, in the present study, given that there is some variability in preventing the LPS translocation in individual goats, it seems reasonable that LPS was detectable in some goats, but not in others, with the high grain diet.

Recent research has shown that feeding high grain diets enhances the concentrations of SAA in the blood of both dairy (Emmanuel, 2008) and beef cattle (Ametaj, 2009) but that the plasma $\mathrm{Hp}$ is not affected. The reason for the increased SAA in the plasma of cattle fed high grain diets is suggested to be related to the translocation of LPS into the systemic circulation, which then stimulates the release of such pro-inflammatory cytokines, such as tumour necrosis factor- $\alpha$, interleukin (IL)-1 and IL- 6 by liver macrophages (Gabay and Kushner, 1999; Ametaj et al., 2011). In our study, the concentration of SAA was increased significantly as the proportion of dietary corn increased, whereas the $\mathrm{Hp}$ levels were not affected, in agreement with reports by Emmanuel (2008) and Ametaj (2009). However, as discussed previously, as the proportion of dietary corn increased, in the current study, LPS became detectable in the blood in some of goats but not in others. The fact that the high grain diet stimulated an inflammatory response, as indicated by increased SAA, in all of the goats but that LPS was only found in the blood of some goats fed the $25 \%$ and $50 \%$ corn concentrate, suggested that the absorbed rumen LPS might not be the only inducer of an acute-phase response with a high grain diet. Previous studies demonstrated that other bacterial immunogens, such as biogenic amine, and Escherichia coli also correlated with an inflammatory response during SARA (Underwood, 1992; Hayward et al., 2006). Therefore, the mechanism regarding the relationship between the inflammation responses and the inflammation stimuli with a high grain diet need to be further evaluated.

\section{Conclusions}

Overall, the results of this study indicate that feeding increasing proportions of corn grain in the diet led to a decreased rumen $\mathrm{pH}$, enhanced concentration of LPS in the rumen fluid, enhanced concentrations of plasma acutephase proteins, such as SAA, and a lower number of Bacteroidetes. Accumulated rumen free LPS could translocate to the bloodstream with a grain diet, but the level of LPS in the peripheral blood varied between individuals. Further research is warranted to gain a better understanding of the relationship between the inflammation responses and all of the abnormal metabolites in the rumen when feeding different grain concentrate diets.

\section{Conflict of interest statement}

None of the authors has any financial or personal relationships that could inappropriately influence or bias the 
content of this report.

\section{ACKNOWLEDGEMENTS}

This work was supported by Natural Science Foundation of China (NSFC) (31172228) and Fundamental Research Funds for the Central Universities (KYZ201114).

\section{REFERENCES}

Alsemgeest, S. P, H. C. Kalsbeek, T. Wensing, J. P. Koeman, A. M. van Ederen, and E. Gruys. 1994. Concentrations of serum amyloid-A (SAA) and haptoglobin (HP) as parameters of inflammatory diseases in cattle. Vet. Q. 16:21-23.

Ametaj, B. N. 2011. Application of acute phase proteins for monitoring inflammatory states in cattle. In Acute Phase Proteins as Early Non-Specific Biomarkers of Human and Veterinary Diseases. F. Veas, ed. InTech, Rijeka, Croatia. Accessed Dec. 22, 2011.

Ametaj, B. N., B. J. Bradford, G. Bobe, R. A. Nafikov, Y. Lu, J. W. Young, and D. C. Beitz. 2005. Strong relationships between mediators of the acute phase response and fatty liver in dairy cows. Can. J. Anim. Sci. 85:165-175.

Ametaj, B. N., D. G. Emmanuel, Q. Zebeli, and S. M. Dunn. 2009. Feeding high proportions of barley grain in a total mixed ration perturbs diurnal patterns of plasma metabolites in lactating dairy cows. J. Dairy Sci. 92:1084-1091.

Andersen, P. H., B. Bergelin and K. A. Christensen. 1994. Effect of feeding regimen on concentration of free endotoxin in ruminal fluid of cattle. J. Anim. Sci. 72:487-491.

Andersen, P. H. 2003. Bovine endotoxicosis-some aspects of relevance to production diseases. A review. Acta Vet. Scand. Suppl. 98:141-155.

AOAC. 1995. Official methods of analysis. 16th ed. Association of Official Analytical Chemists, Arlington, Virginia.

Aschenbach, J. R., T. Seidler, and F. Ahrens. 2003. Luminal salmonella endotoxin affects epithelial and mast cell function in the proximal colon of pigs. Scand. J. Gastroenterol. 38:719726.

Baker, S. B. and W. H. Summerson. 1941. The colorimetric determination of lactic acid in biological material. J. Biol. Chem. 138:535-554.

Baumann, H. and J. Gauldie. 1994. The acute phase response. Immunol. Today 15:74-80.

Beauchemin, K. and G. Penner. 2009. New developments in understanding ruminal acidosis in dairy cows. Tri-State Dairy Nutrition Conference 21-22 April 2009. pp. 1-12.

Boosman, R., T. A. Niewold, C. W. Mutsaers, and E. Gruys. 1989. Serum amyloid A concentrations in cows given endotoxin as an acute-phase stimulant. Am. J. Vet. Res. 50:1690-1694.

Chen, Y., M. Oba, and L. L. Guan. 2012. Variation of bacterial communities and expression of Toll-like receptor genes in the rumen of steers differing in susceptibility to subacute ruminal acidosis. Vet. Microbiol. 159:451-459.

Denman, S. E. and C. S. McSweeney. 2006. Development of a real-time PCR assay for monitoring anaerobic fungal and cellulolytic bacterial populations within the rumen. FEMS Microbiol. Ecol. 58:572-582.
Dunlop, R. H. 1972. Pathogenesis of ruminant lactic acidosis. Adv. Vet. Sci. Comp. Med. 16: 259-302.

Eckersall, P. D. and R. Bell. 2010. Acute phase proteins: Biomarkers of infection and inflammation in veterinary medicine. Vet. J. 185:23-27.

Eckersall, P. D. and J. G. Conner. 1988. Bovine and canine acute phase proteins. Vet. Res. Commun. 12:169-178.

Emmanuel, D. G. V., K. L. Madsen, T. A. Churchill, S. M. Dunn, and B. N. Ametaj. 2007. Acidosis and lipopolysaccharide from Escherichia coli B:055 cause hyperpermeability of rumen and colon tissues. J. Dairy Sci. 90:5552-5557.

Emmanuel, D. G. V., S. M. Dunn, and B. N. Ametaj. 2008. Feeding high proportions of barley grain stimulates an inflammatory response in dairy cows. J. Dairy Sci. 91:606-614.

Fernando, S. C., II H. T. Purvis, F. Z. Najar, L. O. Sukharnikov, C. R. Krehbiel, T. G. Nagaraja, B. A. Roe and U. DeSilva. 2010. Rumen microbial population dynamics during adaptationto a high-grain diet. Appl. Environ. Microbiol. 76:7482-7490.

Gabay, C. and I. Kushner. 1999. Acute phase proteins and other systemic responses to inflammation. New Engl. J. Med. 340: 448-454.

González, F. H., F. Tecles, S. Martínez-Subiela, A. Tvarijonaviciute, L. Soler, and J. J. Cerón. 2008. Acute phase protein response in goats. J. Vet. Diagn. Invest. 20:580-584.

Gozho, G. N., D. O. Krause, and J. C. Plaizier. 2007. Ruminal lipopolysaccharide concentration and inflammatory response during grain-induced subacute ruminal acidosis in dairy cows. J. Dairy Sci. 90:856-866.

Gozho, G. N., J. C. Plaizier, D. O. Krause, A. D. Kennedy, and K. M. Wittenberg. 2005. Subacute ruminal acidosis induces ruminal lipopolysaccharide endotoxin release and triggers an inflammatory response. J. Dairy Sci. 88:1399-1403.

Guo, X., X. Xia, R. Tang, J. Zhou, H. Zhao, and K. Wang. 2008. Development of a real-time PCR method for Firmicutes and Bacteroidetes in faeces and its application to quantify intestinal population of obese and lean pigs. Lett. Appl. Microbiol. 47: 367-373.

Hayward, R. D., J. M.. Leong, V. Koronakis, and K. G. Campellone. 2006. Exploiting pathogenic Escherichia coli to model transmembrane receptor signalling. Natl. Rev. Microbiol. 4:358-370.

Horadagoda, N. U., K. M. Knox, H. A. Gibbs, S. W. Reid, A. Horadagoda, S. E. Edwards, and P. D. Eckersall. 1999. Acute phase proteins in cattle: Discrimination between acute and chronic inflammation. Vet. Rec. 144:437-441.

Hurley, J. C. 1995. Endotoxemia: methods of detection and clinical correlates. Clin. Microbiol. Rev. 8:268-292.

Khafipour, E., D. O. Krause, and J. C. Plaizier. 2009a. A grainbased subacute ruminal acidosis challenge causes translocation of lipopolysaccharide and triggers inflammation. J. Dairy Sci. 92:1060-1070.

Khafipour, E., S. Li, J. C. Plaizier, and D. O. Krause. 2009b. Rumen microbiome composition determined using two nutritional models of subacute ruminal acidosis. Appl. Environ. Microbiol. 75:7115-7124.

Kleen, J. L., G. A. Hooijer, J. Rehage, and J. P. Noordhuizen. 2003. Subacute ruminal acidosis (SARA): a review. J. Vet. Med. Series A 50:406-414.

Krishnamoorthy, U., T. V. Muscato, C. J. Sniffen, and P. J. 
VanSoest. 1982. Nitrogen fractions of selected feedstuffs. J. Dairy Sci. 65:217-225.

Ley, R. E., P. J. Turnbaugh, S. Klein, and J. I. Gordon. 2006. Microbial ecology: human gut microbes associated with obesity. Nature 444:1022-1023.

Li, S., E. Khafipour, D. O. Krause, A. Kroeker, J. C. RodriguezLecompte, G. N. Gozho, and J. C. Plaizier. 2012. Effects of subacute ruminal acidosis challenges on fermentationand endotoxins in the rumen and hindgut of dairy cows. J. Dairy Sci. 95:294-303.

Mao, S. Y., G. Zhang, and W. Y. Zhu. 2008. Effect of disodium fumarate on ruminal metabolism and rumen bacterial communities as revealed by denaturing gradient gel electrophoresis analysis of $16 \mathrm{~S}$ ribosomal DNA. Anim. Feed Sci. Technol. 140: 293-306.

Nagaraja, T. G., E. E. Bartley, L. R. Fina, H. D. Anthony, and R. M. Bechtle. 1978. Evidence of endotoxins in the rumen bacteria of cattle fed hay or grain. J. Anim. Sci. 47:226-234.

Nagaraja, T. G. and K. F. Lechtenberg. 2007. Acidosis in feedlot cattle. Vet. Clin. North Am. Food Anim. Pract. 23:333-350.

Nagaraja, T. G. and E. C. Titgemeyer. 2007. Ruminal acidosis in beef cattle: the current microbiological and nutritional outlook. J. Dairy Sci. 90(Suppl 1):E17-38.

Nazifi, S., S. M. Razavi, Z. Esmailnejad, and H. Gheisari. 2009. Study on acute phase proteins (haptoglobin, serum amyloid A, fibrinogen, and ceruloplasmin) changes and their diagnostic values in bovine tropical theileriosis. Parasitol. Res. 105:41-46.

Nocek, J. E. 1997. Bovine acidosis: Implications on laminitis. J. Dairy Sci. 80:1005-1028.

NRC, 2007. Nutrient requirements of small ruminants: Sheep, goats, cervids and new world camelids. National Research Council, National Academies Press, Washington, USA.
Penner, G. B., M. Taniguchi, L. L. Guan, K. A. Beauchemin, and M. Oba. 2009. Effect of dietary forage to concentrate ratio on volatile fatty acid absorption and the expression of genes related to volatile fatty acid absorption and metabolism in ruminal tissue. J. Dairy Sci. 92:2767-2781.

Plaizier, J. C., D. O. Krause, G. N. Gozho, and B. W. McBride. 2008. Subacute ruminal acidosis in dairy cows: the physiological causes, incidence and consequences. Vet. J. 176: 21-31.

Steele, M., A. O. AlZahal, S. E. Hook, J. Croom, and B. W. McBride. 2009. Ruminal acidosis and the rapid onset of ruminal parakeratosis in a mature dairy cow: a case report. Acta Vet. Scand. 51: 39

Stenfeldt, C., P. M. Heegaard, A. Stockmarr, K. Tjørnehøj, and G. J. Belsham. 2011. Analysis of the acute phase responses of Serum Amyloid A, Haptoglobin and Type 1 Interferon in cattle experimentally infected with foot-and-mouth disease virus serotype O. Vet. Res. 42:66.

Stone, W. C. 2004. Nutritional approaches to minimize subacute ruminal acidosis and laminitis in dairy cattle. J. Dairy Sci. 87: E13-26.

Underwood, W. J. 1992. Rumen lactic acidosis. Part II. Clinical signs, diagnosis, treatment, and prevention. The Compendium for continuing education for the practicing veterinarian 14 : $1265-1270$

Wells, J. E. and J. B. Russell. 1996. Why do many ruminal bacteria die and lyse so quickly? J. Dairy Sci. 79:1487-1495.

Zebeli, Q. and B. U. Metzler-Zebeli. 2012. Interplay between rumen digestive disorders and diet-induced inflammation in dairy cattle. Res. Vet. Sci. 93:1009-1108

Zebeli, Q., J. Dijkstra, M. Tafaj, H. Steingass, B. N. Ametaj, and W Drochner. 2008. Modeling the adequacy of dietary fiber in dairy cows based on the responses of ruminal $\mathrm{pH}$ and milk fat production to composition of the diet. J. Dairy Sci. 91:20462066. 